\title{
Carbon Nanoparticles as Detection Label for Diagnostic Antibody Microarrays
}

\author{
Aart van Amerongen ${ }^{1,2,}$, Geert A.J. Besselink ${ }^{3}$, \\ Martina Blazkova4, Geertruida A. Posthuma-Trumpie', \\ Marjo Koets ${ }^{1}$ and Brigit Beelen-Thomissen ${ }^{1}$ \\ ${ }^{1}$ Wageningen University and Research Centre, \\ Food and Biobased Research - Biomolecular Sensing and Diagnostics, \\ ${ }^{2}$ Laboratory of Organic Chemistry, Wageningen University, \\ ${ }^{3} \mathrm{MESA}^{+}$Institute for Nanotechnology, University of Twente, \\ 4Institute of Chemical Technology, University of Prague, \\ 1,2,3 The Netherlands, \\ ${ }^{4}$ Czech Republic
}

\section{Introduction}

The presence of harmful pathogenic microorganisms is a growing problem in healthcare, food, feed and the environment. In addition, the increasing appearance of antibiotic resistant microorganisms adversely affects this situation. In the current standard detection methods time-consuming and expensive enrichment protocols are being used. Generally, these methods need to be performed in highly equipped laboratories by trained personnel. Often the time needed to confirm the presence of a particular pathogen using standard methods averages 2 to 7 days, which is too long to timely take actions. In human health for example this lack of speed can result in lost working hours, hospitalization or even death. The recent outbreak of food-borne Escherichia coli in Germany and other European countries (May 2011) has shown the dramatic consequences of pathogen contaminated food (Askar et al. 2011; Frank et al. 2011). Apart from E. coli there are several other pathogenic microorganisms that have to be monitored intensively in the food chain. Amongst those are Bacillus cereus, Listeria monocytogenes and Salmonella typhimurium. As different strains of these species may have various degrees of pathogenicity it is very informative to be able to discriminate between harmless and harmful strains. In food production good manufacturing programs were set up to ensure food safety. To comply with these safety rules it would be advantageous to have a versatile, fast, low-cost and on-site assay format available for (on-line) monitoring of food-borne pathogens with a suitable number of target organisms. In the majority of diagnostic questions this number is 5 to maximally 10 .

Many efforts have been made to speed up the detection of harmful microorganisms, the focus of these developments being on faster, more sensitive and more convenient methods (Mandal et al. 2011). Especially when handling large amounts of samples it is a great asset if a detection method allows for medium- to high-throughput screening. In these cases it is 
also valuable if the steps from sample processing to read-out of the results have been maximally automated.

In drug discovery and life sciences research both DNA and, increasingly, protein microarrays are crucial tools (Timlin 2006), whereas the application of microarrays as diagnostics is very promising (Venkatasubbarao 2004). Pathogen detection in food by DNA microarrays has been reported by various groups (D'Agostino et al. 2004; Glynn et al. 2006; Kostrzynska \& Bachand 2006; Volokhov et al. 2002). However, despite its high potential the microarray platform is still not an emerging tool in the regular diagnostic field, especially in the case of protein microarrays (Dieterle \& Marrer 2008). Several reasons may be responsible for this limited presence of protein microarrays such as the lack of sufficient biological recognition elements (e.g., antibodies) and/or their sensitivity and specificity and the inferior conformational stability that some proteins may have. Many problems have still to be overcome for validated in vitro diagnostics using protein microarrays (Hartmann et al. 2009).

To increase the applicability and to reduce the costs of protein microarrays we investigated the use of carbon nanoparticles as signal labels and a conventional flatbed scanner to digitize the image. A nucleic acid detection format was used employing double-tagged amplicons that can be sandwiched between array-immobilised anti-tag antibodies and neutravidin coated carbon nanoparticles. The image was processed using image analysis software to produce the pixel grey volume of the spots generated by the label. As an alternative label to gold and latex, carbon nanoparticles have been used to develop lateral flow immunoassays (LFIA) for over 15 years (Aldus et al. 2003; Capps et al. 2004; Kalogianni et al. 2011; Koets et al. 2006; Koets et al. 2011; Lonnberg et al. 2008; Noguera et al. 2011; Posthuma-Trumpie et al. 2008; van Amerongen et al. 1993; van Amerongen \& Koets 2005; van Dam et al. 2004). The possibility to use the pixel grey volume of the carbon particles in data processing following digitization by a CCD camera and image analysis was already shown in 1994 in a comparison between a simple one-step lateral flow immunoassay and a radioimmunoassay specific for the human choriogonadotropin hormone (van Amerongen et al. 1994). Excellent agreement was achieved among these two techniques with a correlation coefficient of 0.999 . The use of a conventional flatbed scanner to digitize carbon lines was described (Lonnberg \& Carlsson 2001), which by that time was 300 times more sensitive than the CCD camera used in 1994 (van Amerongen et al. 1994). In a recent PubMed literature survey conducted by FIND Diagnostics and published in Clinical Chemistry on the sensitivity of lateral flow immunoassays (Gordon \& Michel 2008) the sensitivity of the carbon label was calculated to be in the low picomolar range for LFIAs specific for a Schistosomiasis carbohydrate antigen and fungal alpha-amylase, respectively, even when the assays were judged by visual inspection (Koets et al. 2006; van Dam et al. 2004). The position occupied by carbon nanoparticles in the sensitivity ranking list of nanoparticles (Gordon \& Michel 2008) holds great promise for the application of these particles as signal labels in microarrays too. Recently, a review about the carbon label in diagnostics has been published (Posthuma-Trumpie et al. 2012).

In this chapter we describe the multi-analyte detection of amplified DNA using an antibody microarray. The nucleic acid detection is based on the use of tagged primers in a PCR resulting in double-tagged amplicons that can be sandwiched between immobilised anti-tag antibodies and neutravidin. Reverse primers were tagged by using biotin and forward 
primers by discriminating tags such as digoxigenin (DIG), dinitrophenol (DNP), fluorescein (FL), and Texas Red (TxR). In this one-step format, the labelled amplicons were mixed with the conjugate of neutravidin and carbon nanoparticles in incubation buffer, immediately applied and detected after one to several hours. Such mixed immuno-DNA formats have been used in lateral flow and microfluidic detection assays (Baeumner 2004; Blazkova et al. 2009; Blazkova et al. 2011; Corstjens et al. 2001; Koets et al. 2009; Kozwich et al. 2000; Mens et al. 2008; Noguera et al. 2011; van Amerongen \& Koets 2005; Wang et al. 2006). To get proof of concept for the use of carbon nanoparticles as signal labels in antibody microarrays we studied two applications in which the antigens consisted of double-tagged DNA amplicons: the detection of L. monocytogenes and the detection of three antibiotic resistance genes from Salmonella spp. (D'Agostino et al. 2004; van Hoek et al. 2005).

\section{Materials and methods}

\subsection{Chemicals}

NeutrAvidin Biotin-Binding Protein (neutravidin) and biotin-labelled bovine serum albumin were from Pierce Biotechnology (Perbio Science Nederland BV, Etten-Leur, The Netherlands); anti-digoxigenin antibody ( $\alpha$-DIG) and $\mathrm{MgCl}_{2}$ were from Roche (Almere, The Netherlands); anti-texas red antibody ( $\alpha-T \times R)$ and goat anti-human immunoglobulin $G$ ( $\alpha-$ hIgG) were from Molecular Probes (Paisly, UK); anti-fluorescein antibody (a-FL) was obtained from Biomeda (Foster City, California, USA) and anti-dinitrophenol antibody (a-DNP) was from USBiological (Swampscott, USA). Human IgG, mouse IgG, Bovine serum albumin (BSA), essentially IgG free, and fluorescein isothiocyanate were from Sigma (Sigma-Aldrich Chemie B.V., Zwijndrecht, The Netherlands). Primers were from Eurogentec (Eurogentec Nederland bv, Maastricht, The Netherlands); dNTPs were from Pharmacia Biotech (GE Healthcare Europe GMBH, Branch office Benelux, Diegem, Belgium). Other chemicals were of the highest purity available and purchased from Merck (Amsterdam, The Netherlands).

\subsection{Polymerase Chain Reaction}

All PCRs were performed in the GeneAmp 970096 well thermal cycler (Applied Biosystems, Foster City, CA, USA). The resulting PCR products were analysed with an Agilent 2100 Bioanalyzer (Agilent Technologies, Santa Clara, CA, USA) using the DNA 1000 kit.

Bacillus cereus: A set of primers was used to amplify part of the gyrB1 gene sequence. The reverse primer was 5'-tagged with DIG and the forward primer with biotin. Primer sequences are shown in Table 1 . The reaction mixture consisted of $1 \mu \mathrm{L} B$. cereus genomic DNA, $25 \mu \mathrm{L}$ redTaq mastermix (Sigma), 10 pmol Rprimer, 10 pmol Fprimer, in a final reaction volume of $50 \mu \mathrm{L}$. The amplification reaction consisted of an initial denaturation step of $5 \mathrm{~min}$ at $94^{\circ} \mathrm{C}$, and 30 cycles of each $30 \mathrm{~s} 94^{\circ} \mathrm{C}, 30 \mathrm{~s} 55^{\circ} \mathrm{C}$ and $1 \mathrm{~min} 72^{\circ} \mathrm{C}$, followed by the final polymerisation at $74^{\circ} \mathrm{C}$ for $5 \mathrm{~min}$. In Fig. 1 a scheme of the technique is depicted.

Listeria spp.: A set of primers specific for L. monocytogenes was used to amplify a part (274 bp) of the prfA gene encoding the central virulence gene regulator as described (Blazkova et al. 2009). One of these primers was $5^{\prime}$-tagged with DIG and the other with biotin. To detect all Listeria species, a generic primer set for amplification of Listeria spp. has been selected (Herman et al. 1995), this primer set has been labelled with fluorescein/biotin. 


\begin{tabular}{|c|c|c|c|c|}
\hline Primer & Sequences & Tag & Specificity & Ref. \\
\hline gyrB Bc1 & 5'-ATTGGTGACACCGATCAAACA-3' & Biotin & B. cereus & $\begin{array}{l}\text { (Chen \& } \\
\text { Tsen 2002) }\end{array}$ \\
\hline$g y r B \mathrm{Bc} 2 \mathrm{r}$ & 5'-TCATACGTATGGATGTTATTC-3' & DIG & B. cereus & $\begin{array}{l}\text { (Chen \& } \\
\text { Tsen 2002) }\end{array}$ \\
\hline prfA LIP1 & 5'-GAT ACA GAA ACA TCG GTT GGC-3' & Biotin & L. monocytogenes & $\begin{array}{l}\text { (D'Agostino } \\
\text { et al. 2004) }\end{array}$ \\
\hline prfA LIP2 & 5'-GTG TAA TCT TGA TGC CAT CAG G-3' & DIG & L. monocytogenes & $\begin{array}{l}\text { (D'Agostino } \\
\text { et al. 2004) }\end{array}$ \\
\hline $\begin{array}{l}\text { 16S rRNA } \\
\mathrm{C}\end{array}$ & 5'-AGG TTG ACC CTA CCG ACTTC-3' & Biotin & Listeria spp. & $\begin{array}{l}\text { (Herman et } \\
\text { al. 1995) }\end{array}$ \\
\hline $\begin{array}{l}\text { 16S rRNA } \\
\text { D }\end{array}$ & 5'-CAA GGA TAA GAG TAA CTG C-3' & FL & Listeria spp. & $\begin{array}{l}\text { (Herman et } \\
\text { al. 1995) }\end{array}$ \\
\hline $\operatorname{tet}(\mathrm{G})-\mathrm{F}$ & 5'AAA GCC GGT TCG CAT CAA AC-3' & DNP & $\begin{array}{l}\text { tetracycline } \\
\text { resistance gene }\end{array}$ & $\begin{array}{l}\text { Van Hoek, } \\
\text { pers. comm. }\end{array}$ \\
\hline $\operatorname{tet}(\mathrm{G})-\mathrm{R}$ & 5'-GGA AGA TCG CAT GTG TTG CC-3' & Biotin & $\begin{array}{l}\text { tetracycline } \\
\text { resistance gene }\end{array}$ & $\begin{array}{l}\text { Van Hoek, } \\
\text { pers. comm. }\end{array}$ \\
\hline aad A2-F & 5'-GCA GCG CAA TGA CAT TCT TG-3' & TxR & $\begin{array}{l}\text { streptomycin } \\
\text { resistance gene }\end{array}$ & $\begin{array}{l}\text { (van Hoek } \\
\text { et al. 2005) }\end{array}$ \\
\hline aadA2-R & 5'-CAT CCT TCG GCG CGA TTT TG-3' & Biotin & $\begin{array}{l}\text { streptomycin } \\
\text { resistance gene }\end{array}$ & $\begin{array}{l}\text { (van Hoek } \\
\text { et al. 2005) }\end{array}$ \\
\hline bla PSE-1- $-\mathrm{F}$ & 5'-CGC TAT CTG AAA TGA ACC AG-3' & DIG & $\begin{array}{l}\beta \text {-lactam } \\
\text { resistance gene }\end{array}$ & $\begin{array}{l}\text { (van Hoek } \\
\text { et al. 2005) }\end{array}$ \\
\hline$b_{\text {blaE-1-R }}$ & 5'-TTT CGC TCT GCC ATT GAA GC-3' & Biotin & $\begin{array}{l}\beta \text {-lactam } \\
\text { resistance gene }\end{array}$ & $\begin{array}{l}\text { (van Hoek } \\
\text { et al. 2005) }\end{array}$ \\
\hline
\end{tabular}

Table 1. Primer sequences used to amplify target microorganisms

S. typhimurium antibiotic resistance genes: The three resistance gene specific forward primers were 5'-tagged with a distinguishing tag: tetracycline with a DNP-tag, streptomycin with a TxR-tag and $\beta$-lactam with a DIG-tag. The reverse primers were labelled with a common biotin tag (Table 1). The amplification was performed using the Accu Prime PCR reaction kit (Invitrogen, Breda, The Netherlands). The reaction mixture consisted of $5 \mu \mathrm{L} 10 \mathrm{x}$ Accu Prime PCR buffer II, 10 pmol primer for the single analyte assay, 20 pmol primers for the multiplexed assay, $2.5 \mathrm{U}$ Accu Prime Taq polymerase, $40 \mathrm{ng}$ genomic DNA in a final volume of $50 \mu \mathrm{L}$. Amplification was performed as follows: $30 \mathrm{~s}$ at $94{ }^{\circ} \mathrm{C}, 30$ cycles of $30 \mathrm{~s}$ at $94{ }^{\circ} \mathrm{C}, 30 \mathrm{~s}$ at $55.8^{\circ} \mathrm{C}$ and $1 \mathrm{~min}$ at $68^{\circ} \mathrm{C}$. After 30 cycles, the mixture was kept at $72^{\circ} \mathrm{C}$ for $7 \mathrm{~min}$.

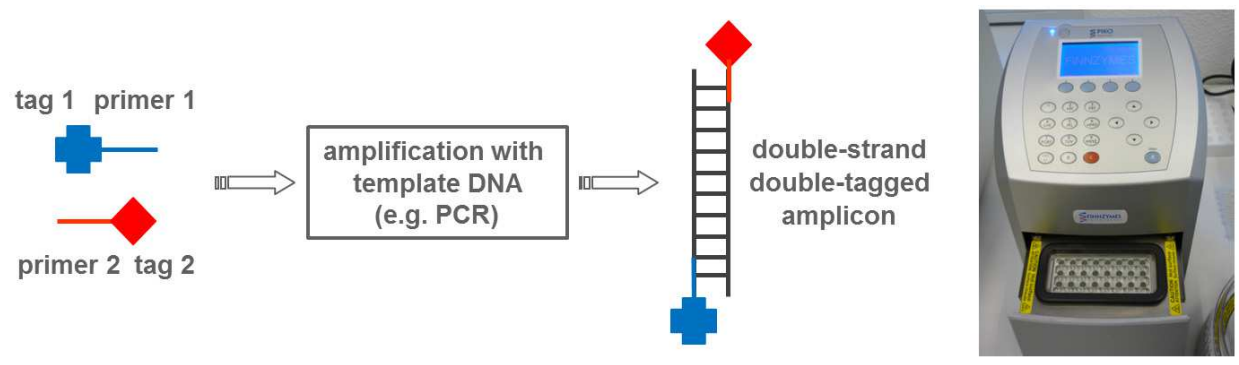

Fig. 1. Scheme of the amplification technique incorporating tags during amplification and a photograph of a low-cost and fast thermocycler to perform the amplification. 
Primer sequences are shown in Table 1. The reaction mixture consisted of $2.5 \mathrm{mM} \mathrm{MgCl}$, $0.15 \mathrm{mM}$ dNTP, $0.1 \mu \mathrm{M}$ primers LIP1 and LIP2, $0.2 \mu \mathrm{M}$ of primers C and D, 2 U FastStart Taq DNA Polymerase (Roche, Almere, The Netherlands), $2 \mu \mathrm{L}$ genomic DNA in a final volume of $25 \mu \mathrm{L}$. The amplification program consisted of an initial denaturation step at $95^{\circ} \mathrm{C}$ for 4 min, 25 cycles each having a denaturation step at $94{ }^{\circ} \mathrm{C}$ for $30 \mathrm{~s}$, annealing at $55^{\circ} \mathrm{C}$ for $30 \mathrm{~s}$ and polymerisation at $74{ }^{\circ} \mathrm{C}$ for $1 \mathrm{~min}$, followed by the final polymerisation at $74{ }^{\circ} \mathrm{C}$ for 5 min.

\subsection{Preparation of carbon nanoparticles - NeutrAvidin conjugate}

Neutravidin was conjugated to colloidal nanoparticles as described in several patents by van Doorn et al. (van Doorn et al. 1987, 1996, 1997). Briefly, a colloidal carbon suspension (Spezial Schwartz 4, Evonik Degussa Industries AG, Essen Germany) was prepared as a stock at $1 \%(\mathrm{w} / \mathrm{v})$ in demineralised water. The suspension was sonicated for 5-10 min on ice using a Branson model 250 sonifier (output control $3 \sim 27 \mathrm{~W}, 20 \mathrm{KHz}$ ). This carbon suspension was diluted five times with $5 \mathrm{mM}$ borate buffer $\mathrm{pH} 8.8$ to give a carbon concentration of $0.2 \%(\mathrm{w} / \mathrm{v})$, and sonicated for a second time as above. Neutravidin dissolved in $5 \mathrm{mM}$ borate buffer $\mathrm{pH} 8.8$ was added to the diluted colloidal carbon suspension at a concentration of $350 \mu \mathrm{g}$ of protein per $\mathrm{mL}$ of suspension. The $\mathrm{pH}$ was readjusted to $\mathrm{pH} 8.8$ and the mixture was incubated overnight by end-over-end mixing at $4{ }^{\circ} \mathrm{C}$. Neutravidin-carbon conjugate was washed two times in a $5 \mathrm{mM}$ borate buffer, $\mathrm{pH} 8.8$, containing $1 \%(\mathrm{w} / \mathrm{v}) \mathrm{BSA}$, and re-suspended and stored in a $100 \mathrm{mM}$ borate buffer, $\mathrm{pH} 8.8$, containing $1 \%(\mathrm{w} / \mathrm{v}) \mathrm{BSA}, 0.02 \%(\mathrm{w} / \mathrm{v}) \mathrm{NaN}_{3}$ as a $0.2 \%(\mathrm{w} / \mathrm{v})$ carbon suspension.

\subsection{Preparation of microarrays}

Antibodies and other proteins were spotted on microscope glass slides by means of a TopSpot device (BioFluidix GmbH, Freiburg, Germany) (de Heij et al. 2004), which is a noncontact printing method. A 24-channel print head was employed for delivering $\approx 1 \mathrm{~nL}$ droplets onto a substrate from which immobilisation of anti-tag antibody and other proteins was allowed to take place (Fig. 2). This resulted in an array of $4 \times 6$ protein spots with a pitch of $500 \mu \mathrm{m}$. Spot diameters are variable and depend on the type of protein, type of substrate, and printing buffer composition and viscosity. In between printing runs the print head was cleaned by ultrasonic treatment for 10 minutes in a $0.12 \mathrm{M} \mathrm{NaOH} / 1 \%$ (v/v) Triton X-100 cleaning solution.
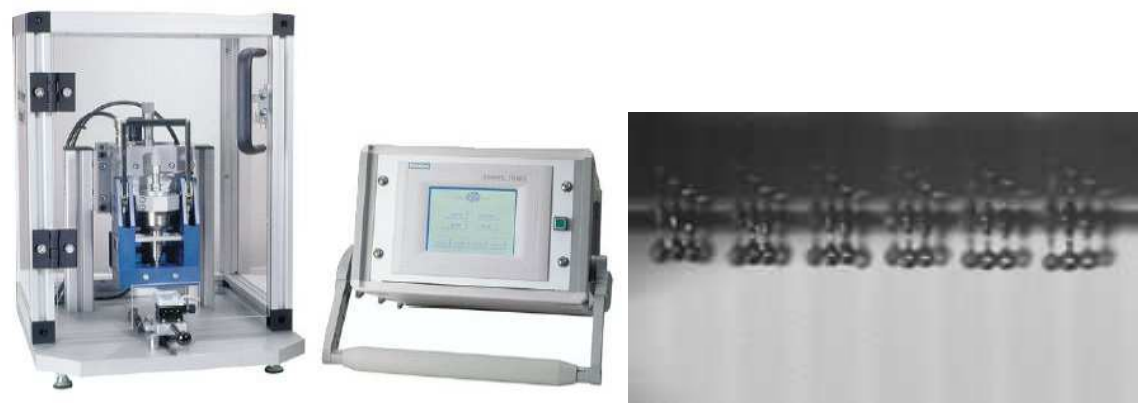

Fig. 2. The Topspot/E (left) and the formation of droplets from the print head (right). 
Three different, commercially obtained, types of glass substrates were used. Antibody arrays of a-DIG, a-FL, a-TxR, and a-DNP were prepared on these very types of substrate as follows:

1. UltraStick slides (Ted Pella Inc., Redding, CA, USA): 3-aminopropyl-triethoxysilane (APTES)-modified glass consisting of a monolayer functionalized with primary amino groups useful for adsorption of proteins. Printing was performed using different concentrations of human IgG, anti-DIG antibody and FL-labelled mouse IgG in PBS. Immediately after arraying, the slides were placed in a humidity chamber and incubated at room temperature for $30 \mathrm{~min}$ in order to allow protein adsorption to proceed. Care was taken to prevent any drying of the spotted droplets. After incubation, the slides were flushed extensively with washing solution $(10 \%$ (w/v) BSA in Phosphate Buffered Saline (PBS)) and arrays were kept covered with fresh washing solution for 10 minutes. Usage of this high protein containing washing solution is essential in order to prevent the smearing of the surplus IgG that had not adsorbed in the first step. Slides containing human IgG spots were incubated with FL-labelled anti-human IgG. Finally, the slides were rinsed quickly with PBS and MilliQ before being dried under a gentle stream of nitrogen gas.

After completion of the procedure, the arrays containing the FL-labelled IgGs were observed by fluorescence microscopy employing an inverted Olympus IX51 microscope equipped with a mercury arc in combination with an Olympus U-MWB2 filter. Images were taken with a digital ColorViewII CCD camera (Soft Imaging Systems, Münster, Germany).

2. SL HCX slides (XanTec bioanalytics $\mathrm{GmbH}$, Düsseldorf, Germany): contain an attached layer of N-hydroxysuccinimide-activated carboxylated hydrogel ( $<5 \mu \mathrm{m}$ thick), attached to borosilicate glass, that can be used for covalent coupling of proteins. Printing was done with different concentrations of anti-DIG and anti-FL antibody in PBS. Directly after printing the array was incubated for $4 \mathrm{~h}$ in a humidity chamber at room temperature. After immobilization, any residual activated groups on the slide surface were quenched by reaction for $10 \mathrm{~min}$ with ethanolamine $(1 \mathrm{M}, \mathrm{pH} 8.0)$ at room temperature. After quenching, the slides were rinsed quickly with MilliQ and, finally, the slides were dried by applying a gentle stream of nitrogen gas.

3. FAST ${ }^{\mathrm{TM}} 16$ slides (Whatman Nederland BV, 's-Hertogenbosch, The Netherlands): on a standard microscope slide are positioned two rows of eight pads $(5 \times 5 \mathrm{~mm})$ of an $11 \mu \mathrm{m}$ thick microporous $(0.2 \mu \mathrm{m}$ pore size) nitrocellulose film for irreversible adsorption of proteins. Arrays of different concentrations and combinations of anti-DIG, anti-FL, antiTxR, and anti-DNP antibodies were spotted on FAST16 slides. Printing buffer was $5 \mathrm{mM}$ borate buffer, $\mathrm{pH}$ 8.8. Immediately after printing the slides were put in an incubator at $37^{\circ} \mathrm{C}$ for 3 hours. No blocking step was used.

\subsection{Amplicon detection assay}

Incubations were performed in a dedicated slide holder with varying amounts $(0.5-2 \mu \mathrm{L})$ $(0.2 \% \mathrm{w} / \mathrm{v})$ of colloidal carbon nanoparticles with immobilised neutravidin (Fig. 3a) and varying amounts $(25,50$ or $75 \mu \mathrm{L})$ of incubation buffer $(100 \mathrm{mM}$ borate, $1 \%$ (w/v) BSA, $0.05 \%(\mathrm{v} / \mathrm{v})$ Tween $20,0.02 \%(\mathrm{w} / \mathrm{v}) \mathrm{NaN}_{3}, \mathrm{pH} 8.8$ ). Following the incubation, positive spots could be easily detected (Fig. 3b) when amplicons were sandwiched between anti-tag antibodies and (black) carbon-neutravidin particles as shown Fig. 3b,c. Control spots (no antibody printed) were used as negative controls. Arrays were recorded by conventional flatbed scanning using an Epson 3200 Photo scanner (Seiko Epson, Nagano, Japan). The 
Pixel Grey Volume of positive spots were obtained using image analysis software (TotalLab, Nonlinear Dynamics, Newcastle upon Tyne, UK). Microsoft Excel and SigmaPlot 11 (Systat Software, Inc., San Jose, CA, USA) were used for subsequent data analysis and visualisation of the results.

a

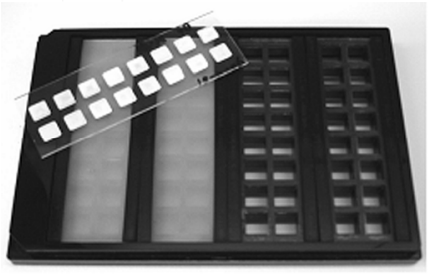

b

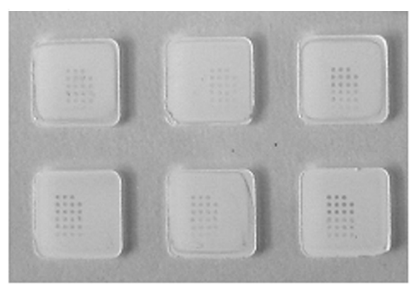

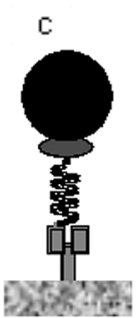

Fig. 3. Overview of antibody microarray tools and the test layout: a) holder for 4 slides with incubation chamber set-up (16 per slide); b) example of six membranes with 24 spot arrays; c) drawing of part of the nitrocellulose membrane with anti-tag antibody, 2-tagged amplicon and neutravidin-coated carbon nanoparticle (not to scale).

\section{Results and discussion}

\subsection{Antibody microarray printing and quality}

One of the advantages of non-contact as compared to contact (pin based and other) printing methods is the inherently lower risk of damaging the substrate surface, which is especially relevant in the case of more fragile structures. This added property is expected to benefit the quality, functionality and reproducibility of the fabricated microarrays.

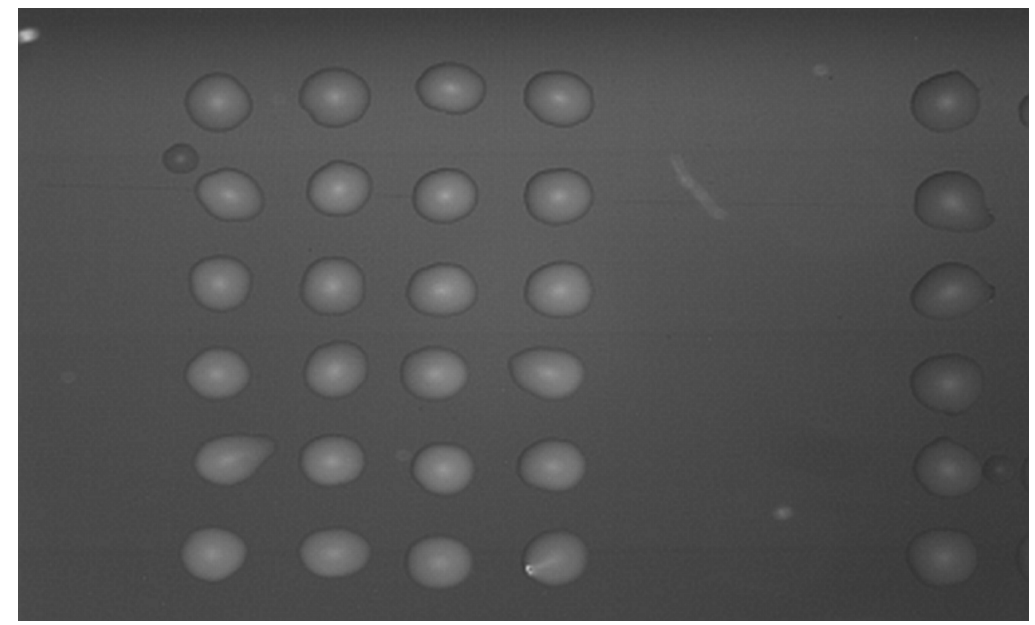

Fig. 4. Droplet microarray obtained after printing of $40 \%$ (v/v) glycerol/water onto bare unmodified glass as observed by light microscopy. 
Unmodified, clean glass has a very hydrophilic nature leading to a tendency for droplets to spread out on the surface and, as a result, to touch each other and to coalesce. This can be overcome by using higher viscosity printing media, for example, $40 \%$ (v/v) glycerol in water. Printing of this solution onto bare glass delivers a nice regular droplet array as shown by the light microscopic image of Fig. 4.

UltraStick slides, on the other hand, are useful substrates for printing of low viscosity solutions, even pure water, with no drop coalescence occurring and thereby yielding a proper array structure. The same is valid, to some lesser degree, for the SL HCX slides.

Interestingly, IgG, BSA and other proteins (e.g., fosforylase B, cytochrome C, streptavidin and neutravidin) tend to adsorb spontaneously onto the UltraStick slide surface. This adsorption is rather strong stemming from the observation that ultrasonic treatment (for $20 \mathrm{~min}$ ) and long soaking (for up to 2 days) in detergent solution (5\% Tween-20 in PBS) did not lead to a significant extent of protein desorption.
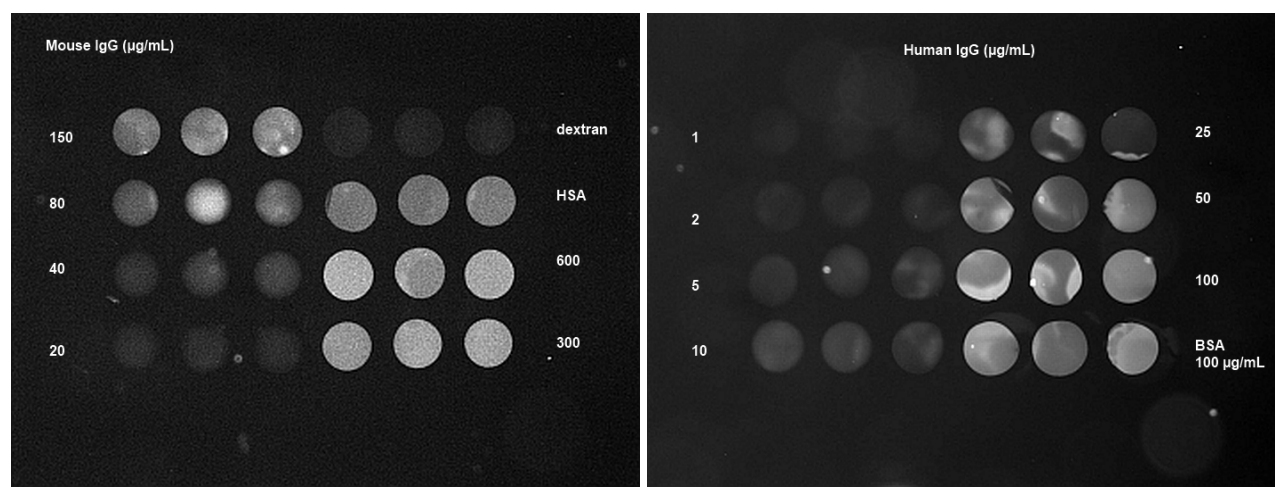

Fig. 5. Fluorescence micrographs of antibody microarrays obtained after printing (in triplicate) of different antibody concentrations on UltraStick slides. Left panel:

fluorescein-labelled Mouse IgG; Right panel: array obtained after printing with human IgG and consecutive incubation of the printed array with fluorescein-labelled goat anti-human IgG. Fluorescein-labelled HSA, BSA and dextran were used as references.

The fluorescence images obtained with arrays of fluorescein-labelled mouse IgG are shown in Fig. 5, left panel. Spot fluorescence intensity increased with increasing printing concentration, in the range from 20 to $300 \mu \mathrm{g} / \mathrm{mL}$.

However, immobilised protein already appeared to be present after printing and incubation at much lower printing concentrations (down to $1 \mu \mathrm{g} / \mathrm{mL}$ ). This was deduced from an amplified detection test in which mouse IgG arrays were incubated with fluorescein-labelled detecting antibody (anti-mouse IgG) (Fig. 5, right panel).

The reproducibility of printing on the UltraStick slides, as judged by fluorescence microscopy on a large number of arrays, seemed to be low. A lot of variation was seen in brightness and brightness pattern when comparing spots. 


\subsection{Amplicon detection assay}

\subsubsection{Introduction}

A series of experiments was performed with Bacillus cereus amplicons to evaluate the signal on three types of microscope slides: UltraStick slides, SL HCX slides and nitrocellulosecoated FAST16 slides.

On nitrocellulose FAST16 slides the detection of Listeria monocytogenes and Listeria 16S rRNA amplicons was optimised for critical parameters such as stirring speed, incubation volume and time, amount of carbon suspension, amount of antibody printed and amount of PCR product added. On the same slides incubations were performed to detect several antibiotic resistance genes from Salmonella spp. The specific amplicons were discriminated by using various tags and the antibodies to those tags were spotted in a distinguishing pattern.

\subsubsection{Choice of target substrate}

A comparison was made between the final yields obtained with UltraStick slides (APTES surface), XanTec slides (pre-activated hydrogel coating) and Whatman FAST16 slides (coated with nitrocellulose). Different amounts of tagged amplicons of $B$. cereus were mixed with various volumes of $0.2 \%(\mathrm{w} / \mathrm{v})$ colloidal carbon nanoparticles-neutravidin conjugate in a total volume of $70 \mu \mathrm{L}$ and incubated at room temperature for $7.5 \mathrm{~min}$ to several hours. Initial results indicated that approximately 0.5 to $2 \mu \mathrm{L}$ of PCR material, $1 \mu \mathrm{L}$ carbon conjugate and incubation for $15 \mathrm{~min}$ to 1 hour is sufficient to obtain significant results by flatbed scanning and image analysis (Fig. 6). Although these results with UltraStick seemed fine in first instance, they were not very reproducible and the response faded very soon after incubation.
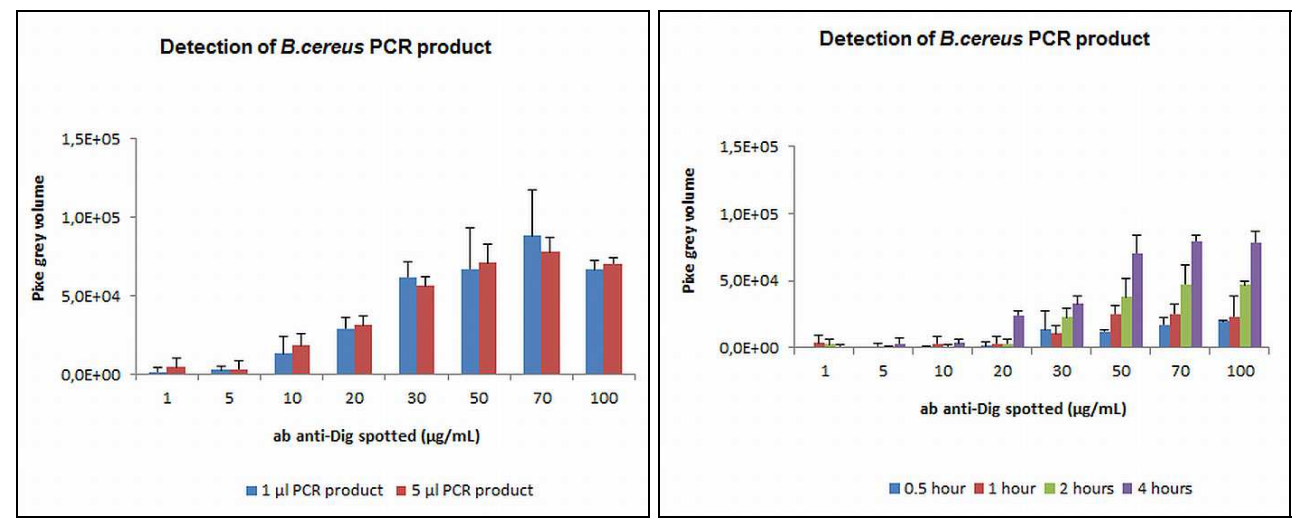

Fig. 6. Antibody microarray with serial dilutions of printed antibodies on UltraStick target. Left panel: influence of amount of amplicon added and antibody concentration, $1 \mu \mathrm{L}$ carbon conjugate, 4 hours incubation time; Right panel influence of antibody concentration and incubation time, $1 \mu \mathrm{L}$ of carbon conjugate and $1 \mu \mathrm{L}$ of amplicon.

The SL HCX hydrogel slides did not deliver much signal in the amplicon detection assay even when larger printing concentrations of IgG (up to $4000 \mu \mathrm{g} / \mathrm{mL}$ ) were applied during 
the preliminary step of array fabrication. Spots became increasingly visible in the concentration range of $400 \mathrm{up}$ to $3000 \mu \mathrm{g} / \mathrm{mL}$, but even then the response remained modest.

The results with the activated hydrogel SL HCX slides were very disappointing, since it was expected that due to its larger loading capacity and presumed lower non-specific binding, the use of such a gel layer could be advantageous compared to a planar sensor surface. Unfortunately, it was not possible to assess the level of porosity of the gel layer and, therefore, it cannot be excluded that it may have limited accessibility for carbon nanoparticles $(\varnothing 100-200 \mathrm{~nm})$. This is supported by our report of a restricted accessibility of sensor hydrogel surfaces toward latex beads (Besselink et al. 2004) that have a size comparable to that of the carbon nanoparticles used in the present study.

Results with Whatman FAST16 slides were promising (Fig. 3b). This was a little bit unexpected considering its behaviour during antibody printing. The hydrophilic coating on the FAST16 slides showed very fast absorption and migration of the liquid from spotted droplets always leading to an extensive overlap of fluid area between neighbouring spots. Nevertheless, in the end, well defined spots were obtained with the colloidal carbon/amplicon test. Apparently, adsorption of antibody (proteins) to the nitrocellulose substrate is an instantaneous process. FAST16 slides were used in all further experiments.

\subsubsection{Single - analyte detection using the antibody microarray}

Increasing the stirring speed from 100 to $500 \mathrm{~min}^{-1}$ revealed that the influence of stirring speed on the final signal is only marginal, at least for the speeds applied (Fig. 7). The stirring speed of $300 \mathrm{~min}^{-1}$ was used in all further experiments. It is shown here that the response is increasing with increasing antibody concentration up to a concentration of $333 \mu \mathrm{g} / \mathrm{mL}$.

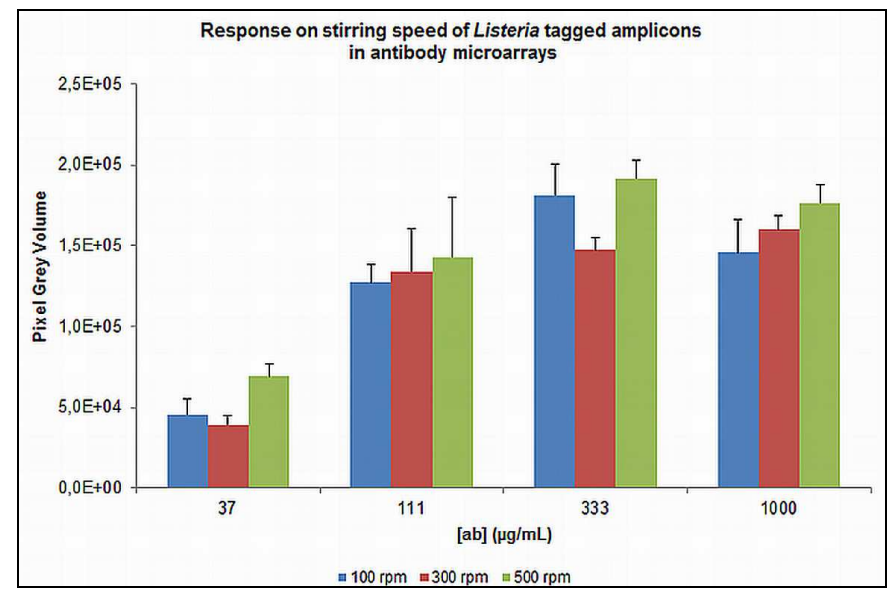

Fig. 7. Influence of stirring speed on pixel grey level, shown for different antibody concentrations, $1 \mu \mathrm{L}$ of carbon-neutravidin conjugate, $1 \mu \mathrm{L}$ of DIG-tagged Listeria amplicons, $25 \mu \mathrm{L}$ total incubation volume and $30 \mathrm{~min}$ incubation time.

A series of incubation times of 7.5 to $60 \mathrm{~min}$ revealed that $30 \mathrm{~min}$ was sufficient to statistically discriminate between different spots if $1 \mu \mathrm{L}$ of amplicon was added (Fig. 8). As 
measured with the Bioanalyzer this volume corresponded to $31.5 \mathrm{ng}$ DNA in the Listeria monocytogenes amplicon solution and to $41 \mathrm{ng}$ in the Listeria spp. amplicon solution.

In another experiment the incubation buffer amount varied from 25, 50 to $75 \mu \mathrm{L}$, which revealed that $25 \mu \mathrm{L}$ is enough for a good and reproducible response, although $75 \mu \mathrm{L}$ is advised by the supplier and, indeed, more convenient. In addition, nitrocellulose pads were better wetted with $75 \mu \mathrm{L}$ as compared to $25 \mu \mathrm{L}$ total volume.
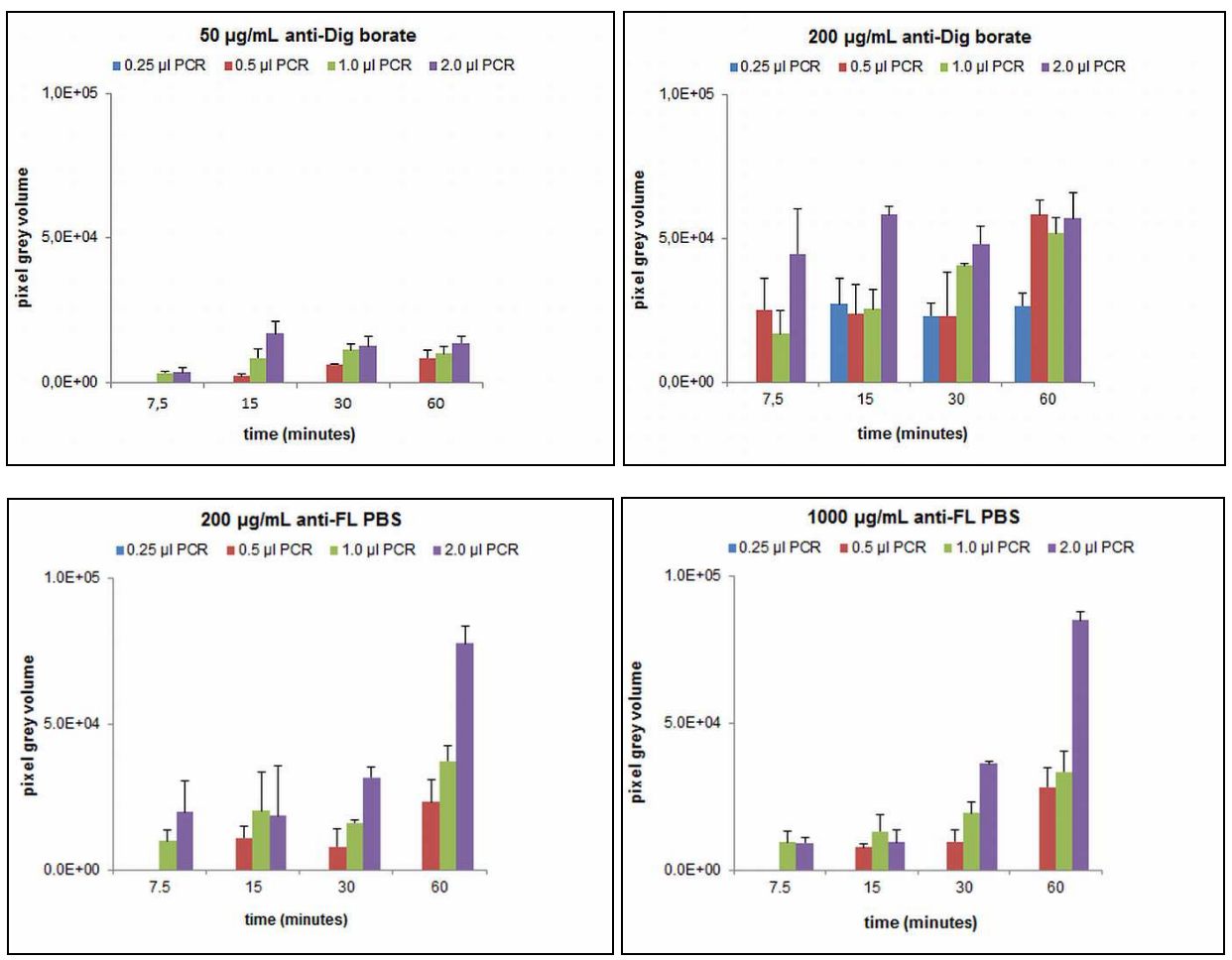

Fig. 8. Influence of incubation time and amount of added amplicon Listeria monocytogenes with DIG as label and Listeria spp. with FL as label. Two concentrations of antibody were spotted with two different printing buffers.

The amount of amplicon added varied from $0.5,1$ to $2 \mu \mathrm{L}$, where $1 \mu \mathrm{L}$ was sufficient to give a good signal, corresponding to an amount of 20-300 fmol sample DNA with similar concentrations of DNA in both samples (31.5 vs. $41 \mathrm{ng}$ DNA/ $\mu \mathrm{L}$ for Listeria monocytogenes amplicon solution and the Listeria spp., respectively). Increasing the concentration of the printed antibody showed an optimum for $333 \mu \mathrm{g} / \mathrm{mL}$ for this combination of labelled amplicon and antibody.

A summary of the influence of buffer volume, antibody concentration and incubation time is shown in Fig. 9 for digoxigenin and in Fig. 10 for fluorescein as a tag. In the case of the antiDIG antibody signal intensity increased upon printing more antibody molecules per spot up to a concentration of $333 \mu \mathrm{g} / \mathrm{mL}$. For the influence of the anti-FL antibody concentration no 
clear conclusions could be drawn. In addition, the total incubation volume was not of much influence, which was similar in the anti-DIG incubations. Whereas in the incubations with the anti-DIG antibody the signal intensity was higher in the 30 minutes as compared to the 10 minutes incubation, no differences could be seen in the case of the anti-FL antibody.

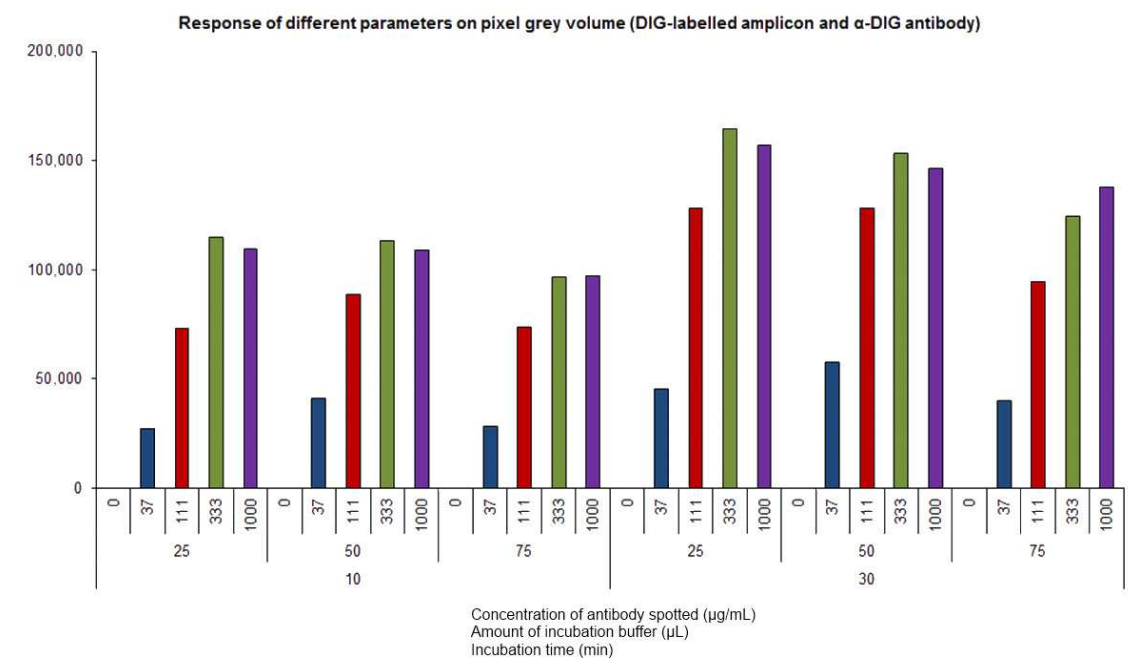

Fig. 9. Influence of the a-DIG antibody concentration (37, 111, 333, or $\left.1000 \mu \mathrm{g} \mathrm{mL}^{-1}\right)$, incubation time (10 or $30 \mathrm{~min}$ ) and volume $(25,50$ or $75 \mu \mathrm{L}$ from left to right) using $1 \mu \mathrm{L}$ of the amplicon of L. monocytogenes labelled with biotin and DIG, $1 \mu \mathrm{L}$ of carbon-neutravidin conjugate, a stirring speed of $300 \mathrm{~min}^{-1}$, and two incubation times: $10 \mathrm{~min}$ or $30 \mathrm{~min}$.

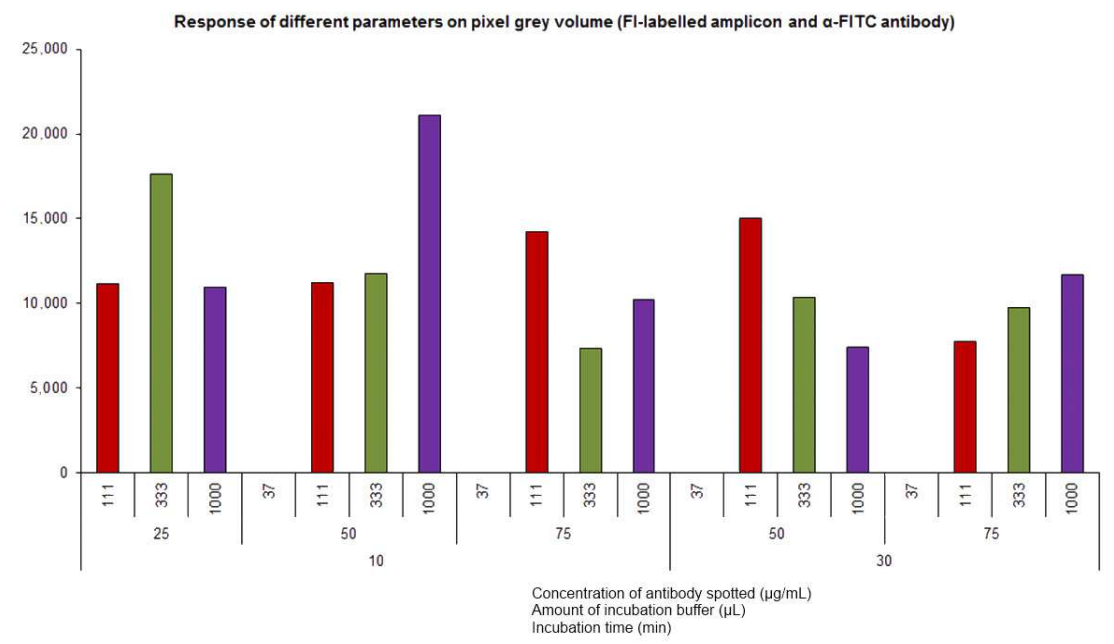

Fig. 10. Influence of the a-FL antibody concentration (37, 111, 333, or $\left.1000 \mu \mathrm{g} \mathrm{mL}^{-1}\right)$; conditions as described under Figure 9 except for the amplicon: $1 \mu \mathrm{L}$ of the amplicon of Listeria 16S RNA labelled with biotin and fluorescein. 
Obviously, optimisation of a microarray immunoassay is dependent on the particular antibodies used and, hence, should be a compromise to enable acceptable sensitivity of all targets involved.

In addition, only PBS was used as a printing buffer, since from the preceding and other (not shown) experiments it was concluded that the results in PBS and in $100 \mathrm{mM}$ borate pH8.8 were very similar. Since commercial antibodies are often shipped in or lyophilized from PBS it was decided to use this buffer in all further experiments.

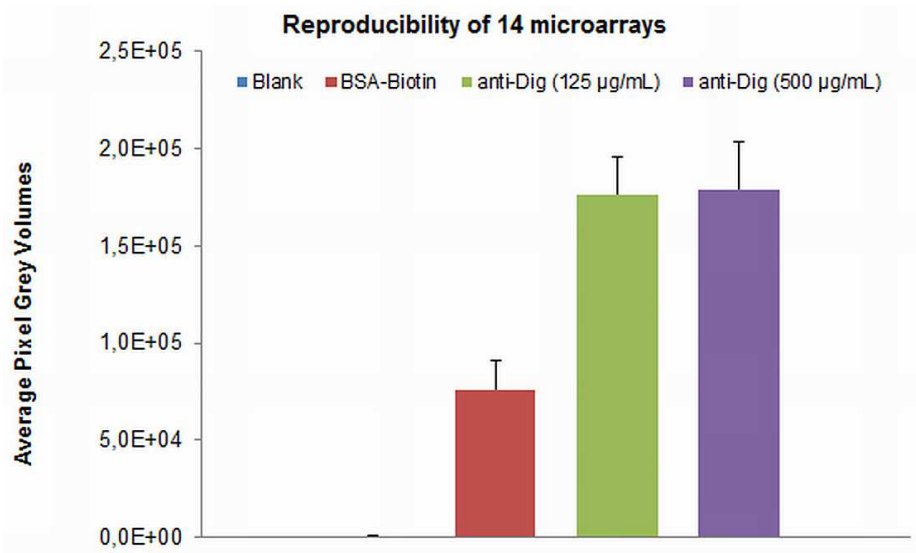

Fig. 11. Reproducibility of a FAST16 slide microarray with $1 \mu \mathrm{L}$ of a L. monocytogenes amplicon using biotin and DIG as the tags, 14 arrays with 9 spots each of BSA-biotin, a-DIG $125 \mu \mathrm{g} \mathrm{mL}-1$, a-DIG $500 \mu \mathrm{g} \mathrm{mL}^{-1}$ and $1 \mu \mathrm{L}$ of carbon conjugate. The total volume was $25 \mu \mathrm{L}$ and samples were incubated for $30 \mathrm{~min}$ at a stirring speed of $300 \mathrm{~min}^{-1}$.

The reproducibility of the assay using the above-mentioned optimized parameters was evaluated using 14 individual microarrays with nine spots each of BSA-biotin $\left(500 \mu \mathrm{g} \mathrm{mL}^{-1}\right)$, a-DIG $\left(125 \mu \mathrm{g} \mathrm{mL}^{-1}\right)$ and a-DIG $\left(500 \mu \mathrm{g} \mathrm{mL}^{-1}\right)$. Amplicons used were $1 \mu \mathrm{L}$ of the DIGlabelled L. monocytogenes type, $1 \mu \mathrm{L}$ of the carbon-conjugate suspension in a total volume of $25 \mu \mathrm{L}$. Incubation time was $30 \mathrm{~min}$. Blanks were evaluated using empty spots. Results are shown in Fig. 11. An intra-assay standard error of less than $10 \%$ was achieved and an interassay standard error of less than $20 \%$ was calculated. These results clearly show the reproducibility of the test.

Optimisation of several parameters in the three-analyte approach was performed using the amplified products of $S$. typhimurium antibiotic resistance genes (Table 1). Serial dilutions of a-TxR, a-DIG or a-DNP antibody $(1000,500,250,125,62.5$ or $31.25 \mu \mathrm{g} \mathrm{mL}-1)$ were printed. Judged from a fixed amount of carbon-neutravidin conjugate $(1 \mu \mathrm{L})$ and serial dilutions of amplicon $(0.125,0.5,1$, or $2 \mu \mathrm{L}), 1 \mu \mathrm{L}$ of each of the amplicons proved to be optimal for a good response (Fig. 12), although $0.125 \mu \mathrm{L}$ could be positively scored in all cases as well. Based on a fixed amount of amplicon (i.e., $1 \mu \mathrm{L}$ ) and serial dilutions of carbon-neutravidin conjugate $(0.5,1,2,4 \mu \mathrm{L})$ the optimal amount of the carbon-neutravidin conjugate suspension was 1-2 $\mu \mathrm{L}$ at antibody concentrations of $125-250 \mu \mathrm{g} \mathrm{mL}^{-1}$ (Fig 12). 

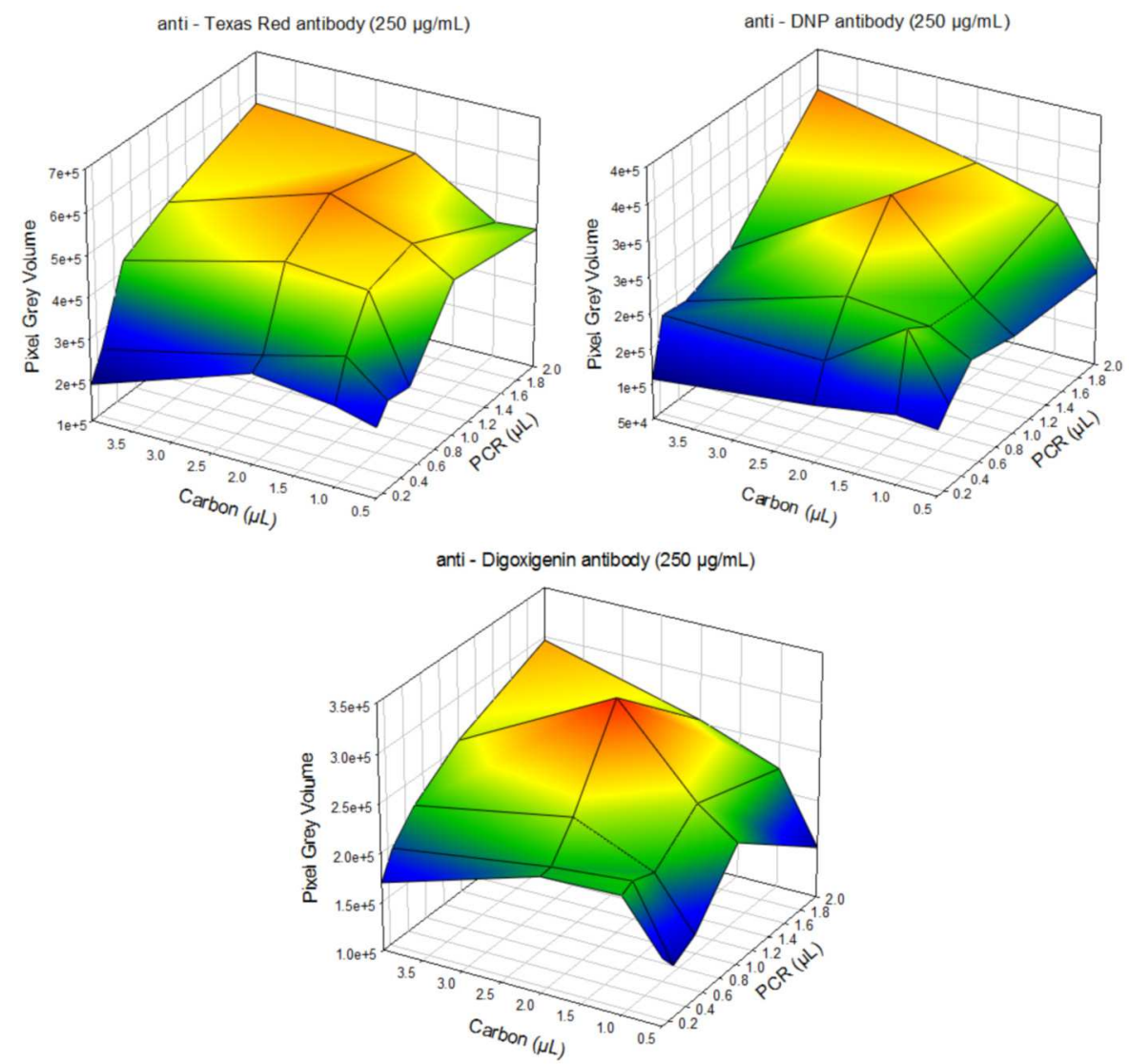

Fig. 12. Contour plots of the influence of addition of amount of amplicon and carbonneutravidin conjugate. Initial results of individual additions of the tagged amplicons of some of the Salmonella antibiotic resistance genes. Shown here are the products tagged with texas red (left upper panel), dinitrophenol (right upper panel) and digoxigenin (lower panel).

\subsubsection{Three - analyte detection using the antibody microarray}

The response of the addition of a mixture of the individually amplified and labelled antibiotic resistance genes is shown in Fig. 13. No quantification of the DNA content of the amplicons was made, and $0.5 \mu \mathrm{L}$ of each amplicon was added to each well. Serial dilutions of antibodies printed showed a concentration-dependent response for every ampliconantibody pair. The total volume was $25 \mu \mathrm{L}$ and the samples were incubated for $30 \mathrm{~min}$, however, in this case $2 \mu \mathrm{L}$ of the carbon conjugate suspension was used.

Signals with the anti-DNP antibodies were twice as high as those with the other anti-tag antibodies and the optimal antibody concentration appeared to be 125 to $250 \mu \mathrm{g} / \mathrm{mL}$. 


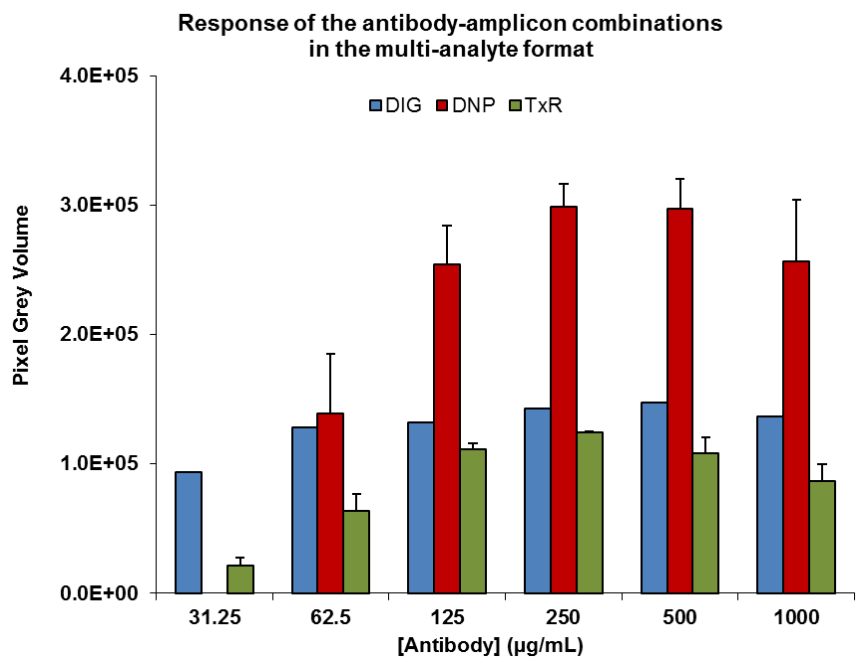

Fig. 13. Response of the multi-analyte format when serial dilutions of the three antibodies were spotted. Incubation was done with addition of $0.5 \mu \mathrm{L}$ of each of the Salmonella amplicons of the antibiotic resistance genes, $2 \mu \mathrm{L}$ of carbon conjugate suspension in $25 \mu \mathrm{L}$ of incubation volume. Incubation time was $30 \mathrm{~min}$.

\begin{tabular}{|c|c|c|c|c|c|}
\hline \multicolumn{3}{|c|}{ Tagged amplicons added } & \multicolumn{3}{|c|}{ Pixel Grey Volume } \\
\hline Dig & DNP & TxR & a-Dig & a-DNP & $a-T \times R$ \\
\hline- & - & - & 0 & 0 & 0 \\
\hline+ & + & + & $1.3 \times 10^{5}$ & $2.5 \times 10^{5}$ & $1.1 \times 10^{5}$ \\
\hline+ & - & - & $1.6 \times 10^{5}$ & 0 & 0 \\
\hline- & + & - & 0 & $3.4 \times 10^{5}$ & 0 \\
\hline- & - & + & 0 & 0 & $1.5 \times 10^{5}$ \\
\hline+ & + & - & $1.7 \times 10^{5}$ & $3.0 \times 10^{5}$ & 0 \\
\hline+ & - & + & $1.6 \times 10^{5}$ & 0 & $1.5 \times 10^{5}$ \\
\hline- & + & + & 0 & $3.2 \times 10^{5}$ & $1.1 \times 10^{5}$ \\
\hline
\end{tabular}

Table 2. Specificity in the three-analyte test (PGV average of 2 tests).

To study whether the simultaneous presence of various targets could be detected in the microarray an experiment was done in which the amplicons, each having a specific DNP, DIG, or TxR tag, were incubated in different combinations. Fixed amounts of anti-tag antibodies were used $(125 \mu \mathrm{g} / \mathrm{mL}$ for each of the antibodies). The results are presented in Table 2. In all cases the presence of a particular amplicon resulted in a high-intensity spot with PGV $>1 \times 10^{5}$. In the absence of a particular amplicon no PGV was detected. Hence, all scores correctly indicated the composition of the various samples.

The most optimal parameters in this format are summarised in Table 3. With minimal volume of $1 \mu \mathrm{L}$ of amplicon (containing 20 to $30 \mathrm{fmol}$ DNA after amplification), a printing 
volume of $1 \mathrm{~nL}$ containing 125-250 pg of antibody (absolute amount) and low-cost resources it is possible to discriminate between three antibiotic resistance genes from Salmonella spp.

\begin{tabular}{|l|l|}
\hline Stirring speed & $300 \mathrm{~min}^{-1}$ \\
\hline Incubation time & $30 \mathrm{~min}$ \\
\hline Volume & 25 to $50 \mu \mathrm{L}$ \\
\hline Antibody spotted & $125-250 \mu \mathrm{g} \mathrm{mL}-1$ \\
\hline Carbon nanoparticles & $2 \mu \mathrm{L}$ \\
\hline PCR amplicon $\left(20\right.$ to $30 \mathrm{fmol} ; 20$ to $\left.300 \mathrm{nmol} \mathrm{L}^{-1}\right)$ & $1 \mu \mathrm{L}$ \\
\hline
\end{tabular}

Table 3. Most optimal parameters in the 3-analyte format.

\subsection{Costs}

Assuming the end-user obtains printed antibody microarrays several costs have to be taken into account. Kits for DNA extraction should be purchased, although recent advances allow for direct PCR on samples if very robust polymerases are being used. Furthermore, some hard- and software is obligatory. These consist of a thermocycler, a personal computer with flatbed scanner or CCD camera and image analysis software. The price of the chemicals (conjugate, PCR reagents) is less than 1 euro per slide. However, one should realize that applications as outlined above, when applied in resource-poor settings, at least need the availability of electricity.

\section{Conclusions and future research}

Carbon nanoparticles with adsorbed neutravidin are suitable as label in nitrocellulose-based antibody microarrays. The versatility has been shown using different types of microorganisms. The format is generic; the only discriminating factor is the sequence of the primers used in the amplification step and the use of the discriminating tag/antibody combination. Although much more space is available on the nitrocellulose pads $(5 \times 5 \mathrm{~mm})$ we used $4 \times 6$ arrays with spots of about $200 \mu \mathrm{m}$ in diameter to study the applicability of the carbon nanoparticles. Unfortunately, there is a paucity in tags and/or their corresponding antibodies that can be used to discriminate between all kinds of food pathogens. Increasing the availability of label/antibody combinations will be a significant improvement in the multi-analyte character of the microarray test procedure as described here.

The best surface for the microarrays as developed in this study is the FAST16 slide with 16 nitrocellulose membranes. We did not have to block the membranes in advance, as is generally done (Jonkheijm et al. 2008). Nevertheless, this one-step procedure resulted in a complete absence of background signal (Fig. 11).

The sensitivity of the proposed microarray procedure with carbon nanoparticles can be improved when a fusion product of neutravidin and enzyme is adsorbed onto the nanoparticles. To this end, neutravidin - alkaline phosphatase and - horseradish peroxidase products are commercially available. Carbon nanoparticles can be labelled with these protein fusion products and specific interaction of these conjugates with biotin-labelled targets results in the presence of a large number of enzyme molecules at the spot. A short, additional incubation step with a precipitating substrate $(10 \mathrm{~min})$ substantially increases the 
signal due to the formation of a precipitable dye on the spot. Preliminary experiments in our laboratory indicate that the sensitivity (PGV) can be increased by a factor 5 to 10 .

Nowadays, various nanoparticles are used in diagnostics, i.e. quantum dots, dye-doped silica, noble metals, and magnetic particles as reviewed (Gomez-Hens et al. 2008). Lönnberg and Carlsson were the first to combine carbon nanoparticles with flatbed scanning (Lonnberg \& Carlsson 2001). Some other authors also mentioned the use of flatbed scanning using gold nanoparticles (Han et al. 2003; Sun et al. 2007; Taton et al. 2000) or enzyme (Petersen et al. 2007). Inexpensive flatbed scanners and CCD-based detectors open new opportunities to develop microarray applications, even for low-facility laboratories and under field conditions (Rasooly \& Herold 2008). Even a visual read-out of the signal is possible when coloured nanoparticles are being used as is valid for the carbon nanoparticles in this study. On the other hand, battery-powered hand-held microarray readers for evaluation of the signal are readily available as well. Since shaking can even be omitted (results not shown) the method can easily be made available to resource-poor settings.

Antibody microarrays are especially applicable when intermediate numbers of samples have to be assayed, application at point of care/need is required, when costs play an important role and highly trained personnel is not available. The presented procedure with signal generation by carbon nanoparticles meets these characteristics.

\section{Acknowledgement}

The generous gift of Salmonella template from Dr A.H.A.M. van Hoek and Dr H.J.M. Aarts (RIKILT, Institute of Food Safety, Wageningen University and Research Centre, The Netherlands) is gratefully acknowledged.

\section{References}

Aldus, C.F., et al. (2003). Principles of some novel rapid dipstick methods for detection and characterization of verotoxigenic Escherichia coli. Journal of Applied Microbiology, Vol. 95, No. 2, (August 2003), pp, 380-389, ISSN 1364-5072

Askar, M., et al. (2011). Update on the ongoing outbreak of haemolytic uraemic syndrome due to Shiga toxin-producing Escherichia coli (STEC) serotype O104, Germany, May 2011. Eurosurveillance, Vol. 16, No. 22, (May 2011), pp, pii=19883, ISSN 1560-7917

Baeumner, A.J. (2004). Nanosensors identify pathogens in food. Food Technology, Vol. 58, No. 8, (August 2004), pp, 51-55, ISSN 0015-6639

Besselink, G.A.J., et al. (2004). Signal amplification on planar and gel-type sensor surfaces in surface plasmon resonance-based detection of prostate-specific antigen. Analytical Biochemistry, Vol. 333, No. 1, (October 2004), pp, 165-173, ISSN 0003-2697

Blazkova, M., et al. (2009). Development of a nucleic acid lateral flow immunoassay for simultaneous detection of Listeria spp. and Listeria monocytogenes in food. European Food Research and Technology, Vol. 229, No. 6, (October 2009), pp, 867-874, ISSN 1438-2377

Blazkova, M., et al. (2011). Immunochromatographic strip test for detection of genus Cronobacter. Biosensors and Bioelectronics, Vol. 26, No. 6, (February 2011), pp, 28282834, ISSN 0956-5663 
Capps, K.L., et al. (2004). Validation of three rapid screening methods for detection of Verotoxin-producing Escherichia coli in foods: Interlaboratory study. Journal AOAC International, Vol. 87, No. 1, (January 2004), pp, 68-77, ISSN 1060-3271

Chen, M.L. \& Tsen, H.Y. (2002). Discrimination of Bacillus cereus and Bacillus thuringiensis with 16S rRNA and gyrB gene based PCR primers and sequencing of their annealing sites. Journal of Applied Microbiology, Vol. 92, No. 5, (May 2002), pp, 912919, ISSN 1365-2672

Corstjens, P., et al. (2001). Use of up-converting phosphor reporters in lateral-flow assays to detect specific nucleic acid sequences: A rapid, sensitive DNA test to identify human papillomavirus type 16 infection. Clinical Chemistry, Vol. 47, No. 10, (October 1, 2001), pp, 1885-1893, ISSN 0009-9147

D'Agostino, M., et al. (2004). A validated PCR-based method to detect Listeria monocytogenes using raw milk as a food model-towards an international standard. Journal of Food Protection, Vol. 67, No. 8, (August 2004), pp, 1646-1655, ISSN 0362-028X

de Heij, B., et al. (2004). Highly parallel dispensing of chemical and biological reagents. Analytical and Bioanalytical Chemistry, Vol. 378, No. 1, (August 2004), pp, 119-122, ISSN 1618-2642

Dieterle, F. \& Marrer, E. (2008). New technologies around biomarkers and their interplay with drug development. Analytical and Bioanalytical Chemistry, Vol. 390, No. 1, (January 2008), pp, 141-154, ISSN 1618-2642

Frank, C., et al. (2011). Large and ongoing outbreak of haemolytic uraemic syndrome, Germany, May 2011. Eurosurveillance, Vol. 16, No. 21, (May 2011), pp, pii=19878, ISSN 1560-7917

Glynn, B., et al. (2006). Current and emerging molecular diagnostic technologies applicable to bacterial food safety. International Journal of Dairy Technology, Vol. 59, No. 2, (May 2006), pp, 126-139, ISSN 1471-0307

Gomez-Hens, A., et al. (2008). Nanostructures as analytical tools in bioassays. Trends in Analytical Chemistry, Vol. 27, No. 5, (May 2008), pp, 394-406, ISSN 0165-9936

Gordon, J. \& Michel, G. (2008). Analytical sensitivity limits for lateral flow immunoassays. Clinical Chemistry, Vol. 54, No. 7, (July 2008), pp, 1250-1251, ISSN 0009-9147

Han, A., et al. (2003). Detection of analyte binding to microarrays using gold nanoparticle labels and a desktop scanner. Lab on a Chip, Vol. 3, No. 4, (September 2003), pp, 329332, ISSN 1473-0197

Hartmann, M., et al. (2009). Protein microarrays for diagnostic assays. Analytical and Bioanalytical Chemistry, Vol. 393, No. 5, (March 2009), pp, 1407-1416, ISSN 1618-2642

Herman, L.M.F., et al. (1995). A multiplex PCR method for the identification of Listeria spp. and Listeria monocytogenes in dairy samples. Journal of Food Protection, Vol. 58, No. 8, (August 1995), pp, 867-872, ISSN 0362-028X

Jonkheijm, P., et al. (2008). Chemical strategies for generating protein biochips. Angewandte Chemie International Edition, Vol. 47, No. 50, (December 2008), pp, 9618-9647, ISSN 1521-3773

Kalogianni, D.P., et al. (2011). Carbon nano-strings as reporters in lateral flow devices for DNA sensing by hybridization. Analytical and Bioanalytical Chemistry, Vol. 400, No. 4, (May 2011), pp, 1145-1152, ISSN 1618-2642 
Koets, M., et al. (2006). A rapid lateral flow immunoassay for the detection of fungal alphaamylase at the workplace. Journal of Environmental Monitoring, Vol. 8, No. 9, (July 2006), pp, 942-946, ISSN 1464-0325

Koets, M., et al. (2009). Rapid DNA multi-analyte immunoassay on a magneto-resistance biosensor. Biosensors and Bioelectronics, Vol. 24, No. 7, (March 2009), pp, 1893-1898, ISSN 0956-5663

Koets, M., et al. (2011). Rapid one-step assays for on-site monitoring of mouse and rat urinary allergens. Journal of Environmental Monitoring, Vol. 13, No. 12, (November 2011), pp, 3475-3480, ISSN 1464-0325

Kostrzynska, M. \& Bachand, A. (2006). Application of DNA microarray technology for detection, identification, and characterization of food-borne pathogens. Canadian Journal of Microbiology, Vol. 52, No. 1, (January 2006), pp, 1-8, ISSN 0008-4166

Kozwich, D., et al. (2000). Development of a novel, rapid integrated Cryptosporidium paroum detection assay. Applied and Environmental Microbiology, Vol. 66, No. 7, (July 1, 2000), pp, 2711-2717, ISSN 0099-2240

Lonnberg, M. \& Carlsson, J. (2001). Quantitative detection in the attomole range for immunochromatographic tests by means of a flatbed scanner. Analytical Biochemistry, Vol. 293, No. 2, (May 2001), pp, 224-231, ISSN 0003-2697

Lonnberg, M., et al. (2008). Ultra-sensitive immunochromatographic assay for quantitative determination of erythropoietin. Journal of Immunological Methods, Vol. 339, No. 2, (December 2008), pp, 236-244, ISSN 0022-1759

Mandal, P.K., et al. (2011). Methods for rapid detection of foodborne pathogens: An overview. American Journal of Food Technology, Vol. 6, No. 2, (July, 2010), pp, 87-102., ISSN 1557-4571

Mens, P.F., et al. (2008). Molecular diagnosis of malaria in the field: development of a novel 1-step nucleic acid lateral flow immunoassay for the detection of all 4 human Plasmodium spp. and its evaluation in Mbita, Kenya. Diagnostic Microbiology and Infectious Disease, Vol. 61, No. 4, (May 2008), pp, 421-427, ISSN 0732-8893

Noguera, P., et al. (2011). Carbon nanoparticles in lateral flow methods to detect genes encoding virulence factors of Shiga toxin-producing Escherichia coli. Analytical and Bioanalytical Chemistry, Vol. 399, No. 2, (October 2010), pp, 831-838, ISSN 1618-2642

Petersen, J., et al. (2007). Detection of mutations in the [beta]-globin gene by colorimetric staining of DNA microarrays visualized by a flatbed scanner. Analytical Biochemistry, Vol. 360, No. 1, (January 2007), pp, 169-171, ISSN 0003-2697

Posthuma-Trumpie, G.A., et al. (2008). On the development of a competitive Lateral Flow ImmunoAssay for progesterone: Influence of coating conjugates and buffer components. Analytical and Bioanalytical Chemistry, Vol. 392, No. 6, (November 2008), pp, 1215-1223, ISSN 1618-2642

Posthuma-Trumpie, G.A., et al. (2012). Amorphous carbon nanoparticles: a versatile label for rapid diagnostic (immuno)assays. Analytical and Bioanalytical Chemistry, Vol. 402, No. 2, (January 2012), pp, 593-600, ISSN 1618-2642

Rasooly, A. \& Herold, K.E. (2008). Food microbial pathogen detection and analysis using DNA microarray technologies. Foodborne Pathogens and Disease, Vol. 5, No. 4, (August 2008), pp, 531-550, ISSN 1535-3141 
Sun, Y., et al. (2007). Label-free detection of biomolecules on microarrays using surfacecolloid interaction. Analytical Biochemistry, Vol. 361, No. 2, (February 2007), pp, 244252, ISSN 0003-2697

Taton, T.A., et al. (2000). Scanometric DNA Array Detection with nanoparticle probes. Science, Vol. 289, No. 5485, (September 2000), pp, 1757-1760, ISSN 00368075

Timlin, J.A. (2006). Scanning microarrays: Current methods and future directions, In: Methods in Enzymology, O. Alan Kimmel and Brian, (Ed), 79-98, Academic Press, ISBN 978-0-12-182816-5, Amsterdam, The Netherlands

van Amerongen, A., et al. (1993). Colloidal carbon particles as a new label for rapid immunochemical test methods: Quantitative computer image analysis of results. Journal of Biotechnology, Vol. 30, No. 2, (August 1993), pp, 185-195, ISSN 0168-1656

van Amerongen, A., et al. (1994). Quantitative computer image analysis of a human chorionic gonadotropin colloidal carbon dipstick assay. Clinica Chimica Acta, Vol. 229, No. 1-2, (September 1994), pp, 67-75, ISSN 0009-8981

van Amerongen, A. \& Koets, M. (2005). Simple and rapid bacterial protein and DNA diagnostic methods based on signal generation with colloidal carbon particles, In: Rapid Methods for Biological and Chemical Contaminants in Food and Feed, A. van Amerongen, D. Barug, M. Lauwaars, (Ed), 105-126, Wageningen Academic Publishers, ISBN 9076998531, Wageningen

van Dam, G.J., et al. (2004). Diagnosis of schistosomiasis by reagent strip test for detection of circulating cathodic antigen. Journal of Clinical Microbiology, Vol. 42, No. 12, (December 1, 2004), pp, 5458-5461, ISSN 0095-1137

van Doorn, A.W.J., et al. (1987). Immunodetermination using non-metallic labels. International Patent Number: 0321008 B1, European Union

van Doorn, A.W.J., et al. (1996). Method for determining the presence of analyte using a stable colloidal carbon sol. International Patent Number: 5,529,901, United States of America

van Doorn, A.W.J., et al. (1997). Stable aqueous carbon sol composition for determining analyte. International Patent Number: 5641689, United States of America

van Hoek, A.H.A.M., et al. (2005). Detection of antibiotic resistance genes in different Salmonella serovars by oligonucleotide microarray analysis. Journal of Microbiological Methods, Vol. 62, No. 1, (July 2005), pp, 13-23, ISSN 0167-7012

Venkatasubbarao, S. (2004). Microarrays - status and prospects. Trends in Biotechnology, Vol. 22, No. 12, (December 2004), pp, 630-637, ISSN 0167-7799

Volokhov, D., et al. (2002). Identification of Listeria species by microarray-based assay. Journal of Clinical Microbiology, Vol. 40, No. 12, (December 2002), pp, 4720-4728, ISSN 0095-1137

Wang, J., et al. (2006). A disposable microfluidic cassette for DNA amplification and detection. Lab on a Chip, Vol. 6, No. 1, (December 2005), pp, 46 - 53, ISSN 1473-0197 


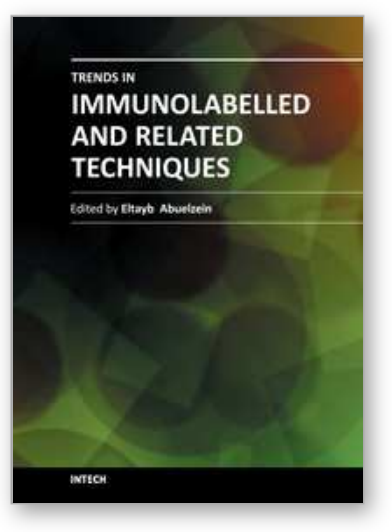

\author{
Trends in Immunolabelled and Related Techniques \\ Edited by Dr. Eltayb Abuelzein
}

ISBN 978-953-51-0570-1

Hard cover, 360 pages

Publisher InTech

Published online 27, April, 2012

Published in print edition April, 2012

The book is coined to provide a professional insight into the different trends of immunoassay and related techniques. It encompasses 22 chapters which are grouped into two sections. The first section consists of articles dealing with emerging uni-and-multiplex immunolabelled methods employed in the various areas of research. The second section includes review articles which introduce the researchers to some immunolabelled techniques which are of vital significance such as the use of the conjugates of the Staphylococcus aureus protein "A" and the Streptococcus Spps. protein "G" in immunolabelled assay systems, the use of bead-based assays and an overview on the laboratory assay systems. The book provides technological innovations that are expected to provide an efficient channel for developments in immunolabelled and related techniques. It is also most useful for researchers and post-graduate students, in all fields, where immunolabelled techniques are applicable.

\title{
How to reference
}

In order to correctly reference this scholarly work, feel free to copy and paste the following:

Aart van Amerongen, Geert A.J. Besselink, Martina Blazkova, Geertruida A. Posthuma-Trumpie, Marjo Koets and Brigit Beelen-Thomissen (2012). Carbon Nanoparticles as Detection Label for Diagnostic Antibody Microarrays, Trends in Immunolabelled and Related Techniques, Dr. Eltayb Abuelzein (Ed.), ISBN: 978-95351-0570-1, InTech, Available from: http://www.intechopen.com/books/trends-in-immunolabelled-and-relatedtechniques/carbon-nanoparticles-as-detection-label-for-protein-microarrays

\section{INTECH}

open science | open minds

\section{InTech Europe}

University Campus STeP Ri

Slavka Krautzeka 83/A

51000 Rijeka, Croatia

Phone: +385 (51) 770447

Fax: +385 (51) 686166

www.intechopen.com

\section{InTech China}

Unit 405, Office Block, Hotel Equatorial Shanghai

No.65, Yan An Road (West), Shanghai, 200040, China

中国上海市延安西路65号上海国际贵都大饭店办公楼405单元

Phone: +86-21-62489820

Fax: $+86-21-62489821$ 
(C) 2012 The Author(s). Licensee IntechOpen. This is an open access article distributed under the terms of the Creative Commons Attribution 3.0 License, which permits unrestricted use, distribution, and reproduction in any medium, provided the original work is properly cited. 